\title{
Application of Dropshipping Method in E-Commerce to Create New Business Opportunities for Students
}

\author{
Dinda Syufradian Putra ${ }^{1,}$, Zulfikar $^{2}$ \\ 1,2Master's Institute of Technology and Business, Pekanbaru, Indonesia
}

\begin{tabular}{l} 
Article Information \\
\hline Article History: \\
Accepted by the Editor: November 14, 2021 \\
Final Revision: November 23, 2021 \\
Published Online: December 31, 2021 \\
Keywords \\
\hline Dropshipping \\
E-Commerce \\
Entrepreneurship \\
Correspondence
\end{tabular}

E-mail: dinda.syufradian@gmail.com*

\section{A B S T R A C T}

This study aims to create new business opportunities for students using information technology (IT) and the internet by becoming entrepreneurs. The basic concept of using IT and the Internet is to be the main actor in the development of e-commerce and to be a part of it by using certain methods. One method that can be applied in e-commerce is the dropshipping method. With this dropshipping method, anyone can sell goods/services without having to have a stock of goods/services simply by collaborating with manufacturers, shops, and suppliers. The method in this research is an experimental research method. Explorative research aims to explore or deepen knowledge, phenomena, and new ideas to formulate problems in detail. From the research results on 32 students who became participants, the success rate of implementing the dropshipping method in this study was $71.87 \%$, namely 23 students succeeded in selling products while nine other students failed to sell products or $28.13 \%$. This direct practice's high level of success can be used as a reference for development and broad application in creating new business opportunities for students by becoming a dropshipper.

\section{Introduction}

The development of information technology and the internet has brought many changes to the economy and business in Indonesia, especially in e-commerce or digital business. In 2015, the President of Indonesia had predicted that Indonesia would become the largest digital economy player in Southeast Asia. Facts prove that in 2021 industry e-commerce has become the backbone of the national economy with the emergence of startups in Indonesia; even the startups own valuations of US \$ 1 billion or popular with the term unicorn. Until 2021, local Indonesian startup companies that already have unicorn status are Gojek, Tokopedia, Traveloka, Bukalapak, OVO, J\&T Express, Online Tax and Xendit.

Along with the development of the start-up company or startup that is dominant in the e-commerce zone, it has opened new business opportunities for the Indonesian people who participate in e-commerce. One of the most popular parts of e-commerce is the emergence of an online shop or online shop incorporated in one of the e-commerce platforms. The main choice is selling products through e-commerce because this business does not require much money for space rental and promotion. The presence of an online digital business or e-commerce is an innovation that can affect the competitive advantage to market a product without limits [1]. 
One method of selling products or services through e-commerce is known as dropshipping. Dropshipping is a method of buying and selling online, namely business entities or individuals, both in online store services and retailers ( dropship), without requiring inventory. Merchandise is obtained from a cooperative relationship with another company that produces or physically owns the goods. Entrepreneurs who do dropship are called drop shippers [2]. Based on this drop shipping concept, anyone can sell products just by displaying photos of the product through accounts on social media. If there is a buyer, the drop shipper will contact the company that produces or owns the goods in question. The rapid development of the e-commerce market in Indonesia today will become a new business opportunity that can be utilized by the Indonesian people in general and students in particular to become drop shippers.

Based on the description above, this study aims to foster an entrepreneurial spirit for students by taking advantage of the development of e-commerce by becoming a dropshipper in the hope of creating new business fields for students. The final result that will be explored in this research is to get an idea of students who already have entrepreneurial knowledge to practice opening a new online-based business as a dropshipper in one of the e-commerce sites.

The e-commerce market in Indonesia with a population of more than 280 million, is a huge market opportunity. This condition underlies the importance of this research, especially for students in creating new business opportunities. E-commerce or electronic commerce is the main characteristic of the information and communication technology revolution in the economic field [3]. One of the countries with the largest ecommerce development globally is China with a population of more than 1.4 billion people with a percentage of 30 percent actively using the internet [4].

The main purpose of e-commerce services is to create a link between the products or services offered, the existence of consumers who carry out the ordering process, the existence of buying and selling transactions and payments, as well as the process of sending goods to consumers as a service standard [5]. Ecommerce can be distinguished based on the nature of the transaction, namely Business to Consumer (B2C), Business to Business (B2B), and Consumer to Consumer (C2C). B2C is a business transaction process between business people and consumers directly, while B2B is a business transaction process between business people, either directly or indirectly. Furthermore, $\mathrm{C} 2 \mathrm{C}$ is a business transaction between consumers as end users among consumers. E-commerce is essentially the same as conventional markets, while the difference is that the transaction process is no longer face-to-face but uses the internet and can be carried out anytime and anywhere. The advantages of e-commerce compared to conventional businesses are: (1) Unlimited products that can be sold; (2) A place to sell products only requires a website and does not require a shop or shophouse which is relatively expensive; (3) Orders via the internet are not made face-to-face or indirectly; (4) Payment methods can be made by cash, transfer, credit card, or other methods; (5) The method of delivery of goods can use any delivery service; (6) The system works online for customer service ; and (7) Save time, effort, and cost. Some of these e-commerce players take only half of the role, namely as agents or intermediaries or better known as adrop shippers [6].

A dropshipper is a person who sells a product, but essentially he does not have the product in stock, so he will order it back to the shop/supplier that provides it. The dropshipping work system is described in Figure 1 below. 


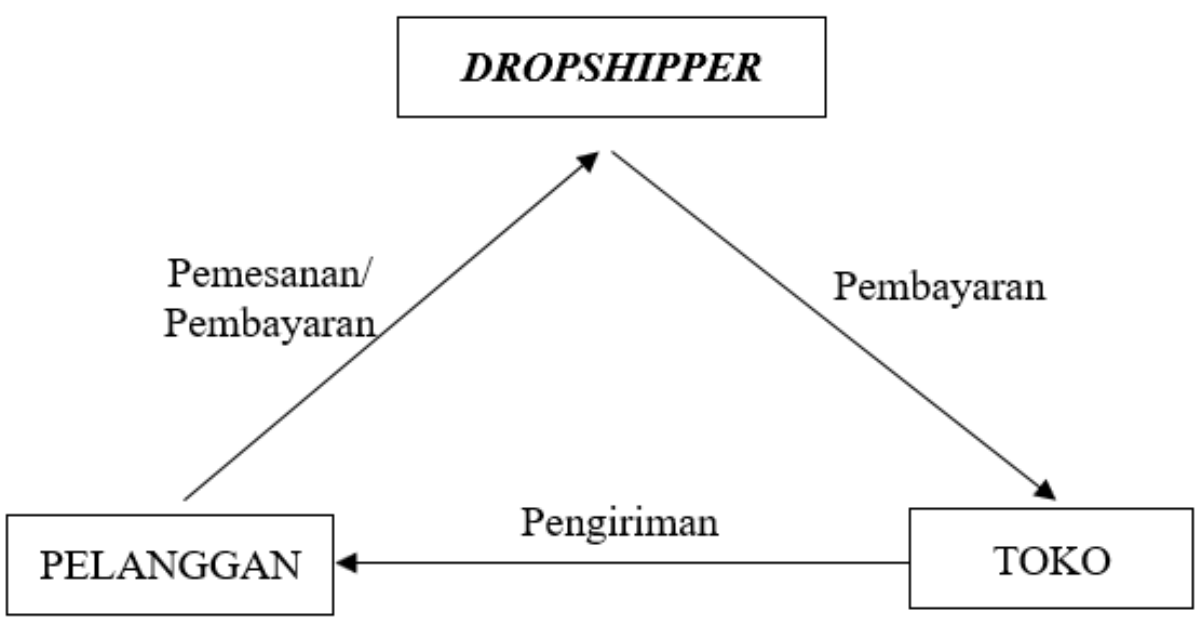

Figure 1. Dropshipping Concept

Based on Figure 1, consumers can search for products or goods offered by accessing online store websites. Business owners or online shops receive purchase data such as product information ordered, delivery and payment destinations, and the identity of the consumer who ordered. The shop owner then processes consumer orders and sends the intended order by dropship through a delivery courier service. The dropshipping method in e-commerce presents many opportunities, especially in developing countries because of high economic growth and community activities in the use of information technology media are very active [7].

Applying the dropshipping method can be successful if effective promotional techniques support it. Effective promotion by utilizing information technology can be applied using smartphone messaging applications, social media such as Facebook, Twitter, Instagram and placing ads on Google or using keywords in popular search engines [8].

By understanding the dropshipping concept, students are expected to run it well. It is what makes this research necessary to be carried out to see how students who already have entrepreneurial knowledge carry out the practice of opening new online-based businesses as drop shippers ?.

\section{Method}

The research method used is an exploratory method. Exploratory research is carried out to find new ideas or relationships from certain phenomena [9]. Exploratory research can be considered the first step to formulate problems on how to solve these problems, which may be solved by using other types of research, such as descriptive or explanatory. Exploratory research looks for some ideas or a new relationship, so it does not require preparation or planning of the formal [10].

This research was conducted at the Institute of Technology and Business Master, with the subjects being 5th-semester students of the management study program who had taken entrepreneurship courses. The number of participants in this research is one class with a total of 32 people. Dropshipping practice is carried out for two weeks (14 days). Participants as research subjects must market at least one (1) product into one of the e-commerce platforms. Products marketed freely and are the property of third parties by cooperating to market their products into e-commerce.

The work steps that participants in this dropshipping practice must take are day 1 making a plan to sell products to be marketed. Days 2 - 3: Collaborating with third parties to market products. Days 4 - 5: Documentation and product uploads in e-commerce applications. Day 6 - 13 Time of product sales in ecommerce applications. Day 14 Documentation and Reports. Furthermore, the documentation and 
participant reports became the primary data sources in this study. The accuracy and validity of data and information are highly dependent on the honesty of the participants who follow the practice of implementing this dropshipping.

The results of the documentation and participant reports were processed and processed descriptively to find new facts that occurred during the 14-day practice to be analyzed and processed further in concluding. The final results of this exploratory study are limited to see how students who have entrepreneurial knowledge can implement new practices to open an online-based business as a dropshipper at one of the ecommerce platforms. New facts and phenomena that emerged during the practice process can be used as references to create new business opportunities for students and the wider community in general.

\section{Results and Discussion}

Based on the results of the studies that have been carried out, there are several new facts in the research, from the results of the analysis of reports and documentation from participants who are students of the Master's Institute of Technology and Business, several new facts and new phenomena that emerged during the 14-day practice period can be described. Application of e-commerce that is used to sell a product is Shopee and Tokopedia. Participants are given the freedom to choose one or both. The use of Shopee and Tokopedia applications is because these two applications are the most widely used applications by internet users in Indonesia, as shown in Figure 2.

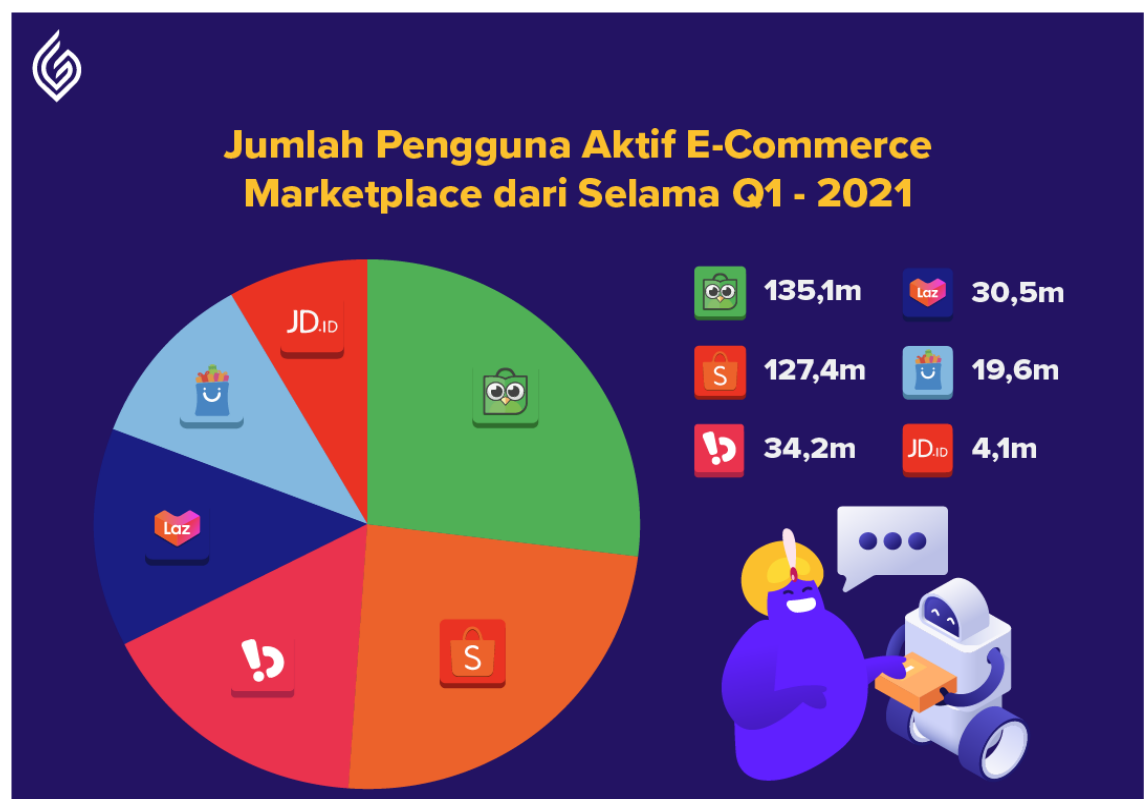

Figure 2. Number of Active Users of E-Commerce Q1 - 2021

From Figure 2 above, it can be seen that the number of users who accessed Tokopedia during Q1 2021 amounted to 135.1 million people and Shopee was in second place with 127.4 million people, followed by Bukalapak with 34.2 million and Lazada 30.5 million people. This can certainly be a reference for choosing the Tokopedia da Shoppe application as the application of choice in the application of this research exploration practice. The next interesting thing to discuss is the level of success of participants in selling products, which can be seen in table 1 below.

Table 1. Dropshipping Implementation Results

\begin{tabular}{cccc}
\hline No & Student & Amount & Description \\
\hline 1 & Successfully Sell Product & 23 & $71,87 \%$ \\
2 & Unsuccessfully Selling Product & 9 & $28,13 \%$ \\
& Amount & $\mathbf{3 2}$ & $\mathbf{1 0 0 , 0 0 \%}$ \\
\hline
\end{tabular}


Based on table 1, it can be seen that of the 32 participants, 23 succeeded in selling the product and nine others failed to sell it. If the percentage is drawn, the success rate of the participants in selling the product is $71.87 \%$. Interesting facts from 23 participants who managed to sell 16 products, 16 of them only managed to sell one product and 7 other participants managed to sell 7 products. Based on this data, participants' chances to successfully sell the product are very high because they can penetrate the $71.87 \%$ figure. This is certainly interesting to be developed and widely applied in creating new business opportunities for students who are still studying. The description of the products sold by the participants can be seen in table 2 .

Table 2. Products Sold by Students

\begin{tabular}{ccc}
\hline No & Product & Description \\
\hline 1 & Clothing (Shirts, Pants and Skirts) & 18 Students \\
2 & Hat & 3 Students \\
3 & Purse & 1 Student \\
4 & Bag & 2 Students \\
5 & Veil & 8 Students \\
\hline
\end{tabular}

From table 2, it can be seen that students' interest in selling products in e-commerce is more dominant in clothing. Of the 32 students, 18 chose to sell clothing products, eight chose to sell hijab, three chose to sell hats, one student chose to sell wallets, and two chose to sell bags. From this data, $56.25 \%$ of students are interested in selling products in the form of clothing. The tendency to sell clothes cannot be separated from the ease with which it is easy to find a third party to cooperate in selling products in e-commerce, either as dropshipping or as a direct reseller from manufacturers or drop shipping partner applications that are popping up a lot nowadays. It is interesting to see how the sales results from participants who follow the practice of selling products with this drop shipping method are in table 3 of the following product sales results.

Table 3. Product Sales Results

\begin{tabular}{ccccc}
\hline No & Product & Amount & Success & Description \\
\hline 1 & Clothing (Shirts, Pants and Skirts) & 18 Students & 15 Students & $83,33 \%$ \\
2 & Hat & 3 Students & 1 Student & $33,33 \%$ \\
3 & Purse & 1 Student & - & - \\
4 & Bag & 2 Students & - & - \\
5 & Veil & 8 Students & 7 Students & $87,5 \%$ \\
\hline
\end{tabular}

From Table 3, the success rate of sales of participants who sell clothes is very high, namely $83.33 \%$. Of the 18 students who tried to sell clothing products, 15 managed to sell the product. While 3 participants tried to sell hats, only one person managed to sell the product. Participants failed in selling the product for bag and wallet products. The highest percentage was achieved by participants who sold Hijab, from 8 people who sold products, 7 of them managed to sell products or $87.5 \%$. The last interesting thing to look at is the comparison of participants by gender and success rate in table 4 .

Table 4. Dropshipping Implementation Results

\begin{tabular}{ccccc}
\hline No & Product & Amount & Success & Description \\
\hline 1 & Male & 7 People & 3 People & $42,85 \%$ \\
2 & Woman & 25 People & 20 People & $80 \%$ \\
\hline
\end{tabular}

From table 4, it can be seen that the success rate of female participants in selling products is $80 \%$ or 20 people out of 25 participants. Meanwhile, the success rate of male participants in selling products is $42.85 \%$, which is only three people out of 7 participants. From this data, it can be concluded that female participants have a higher success rate than male participants.

In implementing this dropshipping, the recommended e-commerce applications are Tokopedia and Shopee. Tokopedia and shopee apply layered security for the databases they use, especially concerning partner data and customer data. For shopee and tokopedia the personal data they collect into the database is the name; email address; date of birth; billing address; bank account and payment information; phone 
number; gender; information sent by or connected to the device used to access the Service; any other information about the User when the User registers to use the Service or Platform. Especially for Tokopedia, Tokopedia has collaborated with the Government through the Ministry of Communication and Information and the National Cyber and Crypto Agency to ensure the security and protection of the personal data of every Tokopedia user that Toppers can continue to transact in peace. Tokopedia also implements layered security, including OTP, which the account owner can only access in real time.

To start becoming a dropshipper on the Tokopedia or Shopee application, the first step that must be done is to have an active email, contact phone number, identity card for verification. After the documents are complete, the registration can go directly to the Tokopedia and Shopee websites. After successfully logging in, the next step is to create a shop as shown in Figure 3.
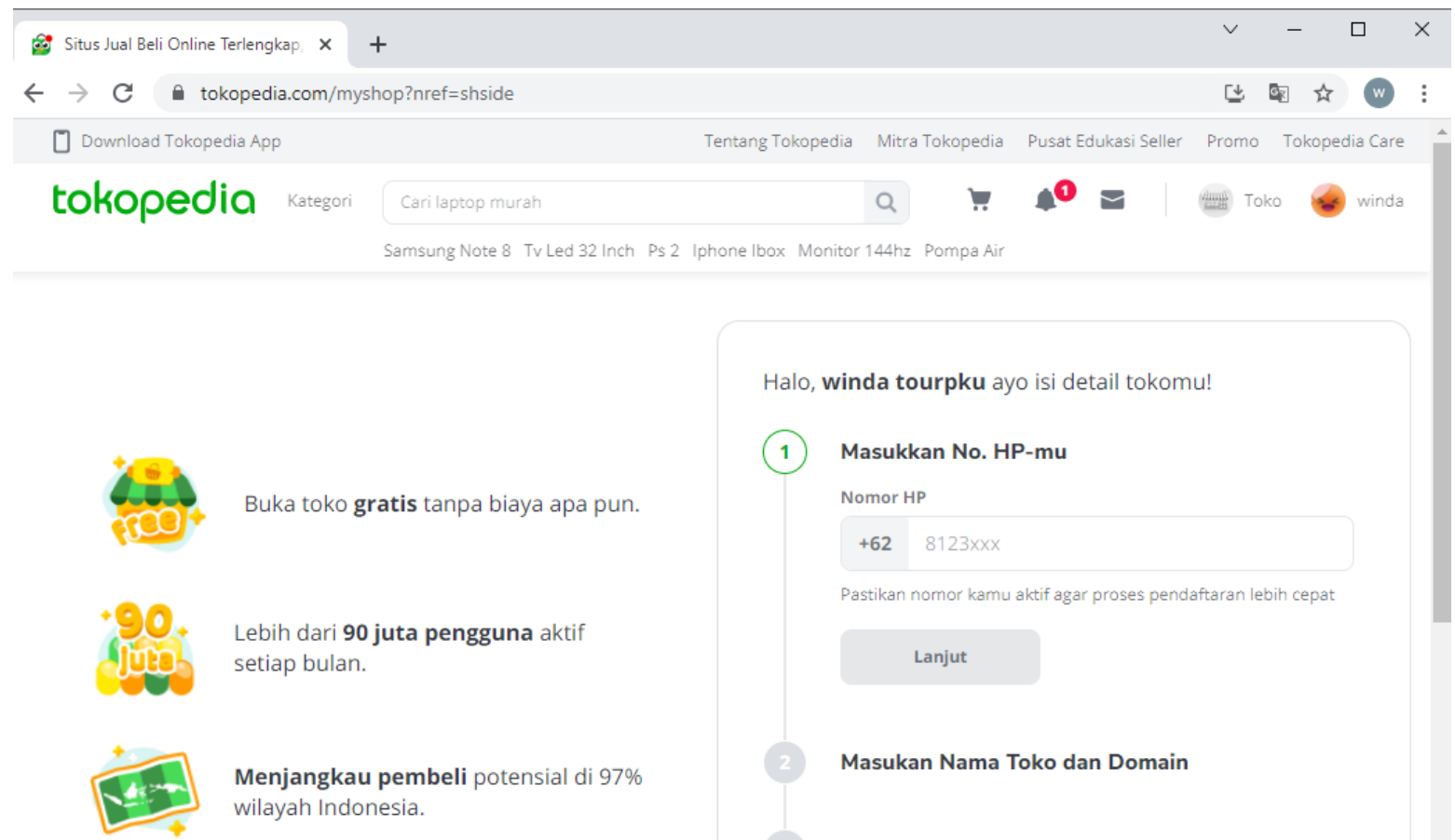

Halo, winda tourpku ayo isi detail tokomu!

(1) Masukkan No. HP-mu

Nomor HP

$+628123 x x x$

Pastikan nomor kamu aktif agar proses pendaftaran lebih cepat

Lanjut

Masukan Nama Toko dan Domain

Masukkan Alamat Tokomu

Figure 3. Initial Display of Shop Creation on Tokopedia

Creating a store on Tokopedia is very easy; all you have to do is enter a phone number or cellphone, enter the name of the store and the address of the store, then, after successful verification the store is ready to be used. For the shopee platform, the shop creation method is more or less the same. Next is the product entry for sale, the steps are as shown in Figure 4. 
tokopedia Seller

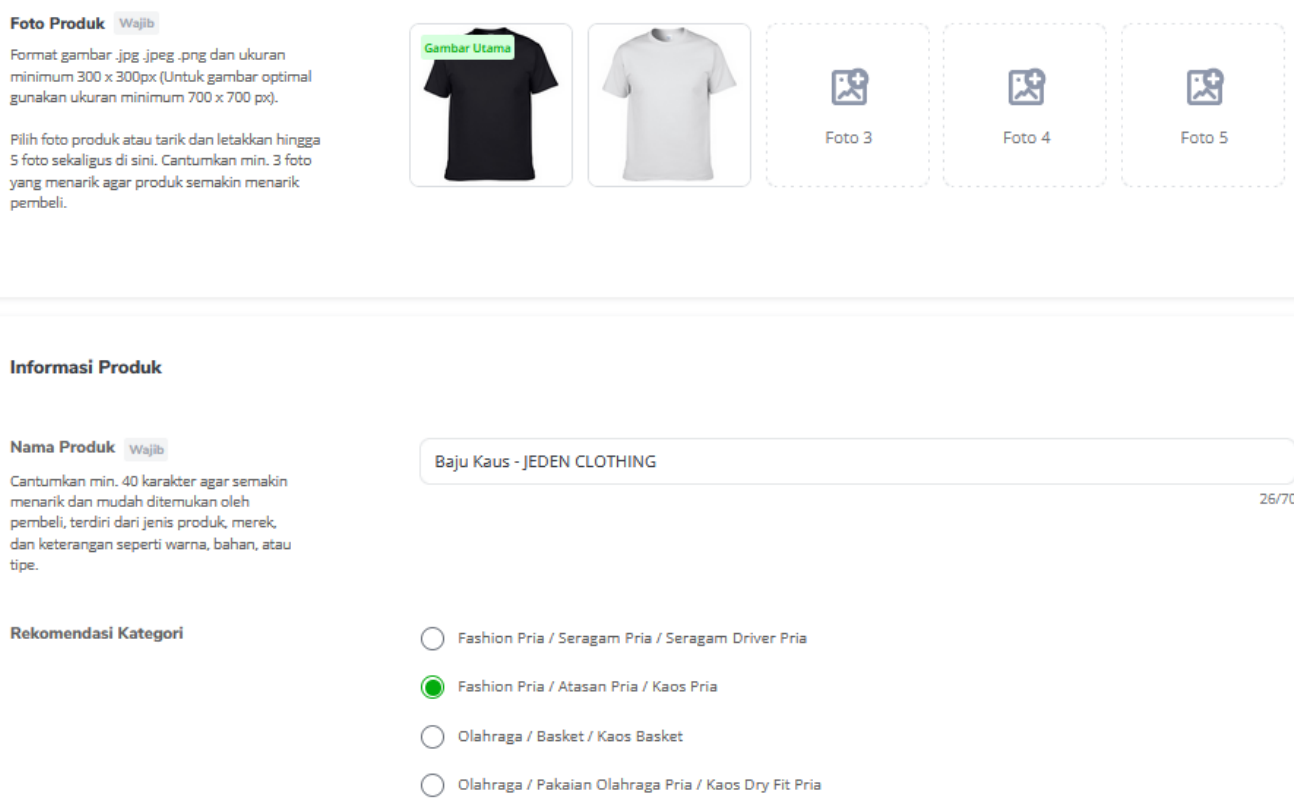

Figure 4. Product Entries Display

Entri The Product Entry process begins with uploading photos and then product categories, prices and product categories. To make it easier for potential buyers to find information about the product, it must be filled in with a complete product description. To view the products that have been entered, see Figure 5.

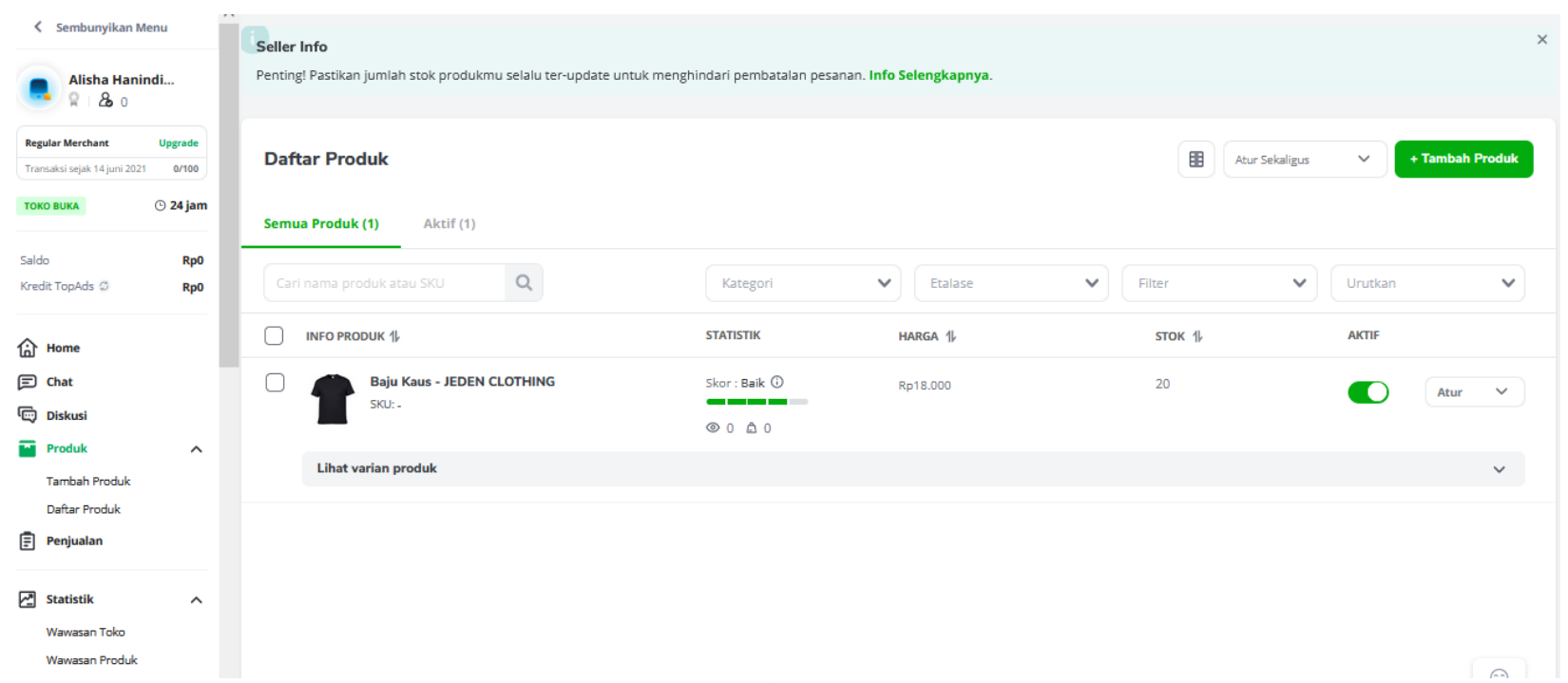

Figure 5. Display of the Entry Product List

From Figure 5, it can be seen that the product that has been entered is complete with statistics on how many times the customer has seen it, the selling price of the product and the remaining stock, then the active and inactive buttons to display the product on the main Tokopedia page for consumers. The shop page display that has been created is as shown in Figure 6. 


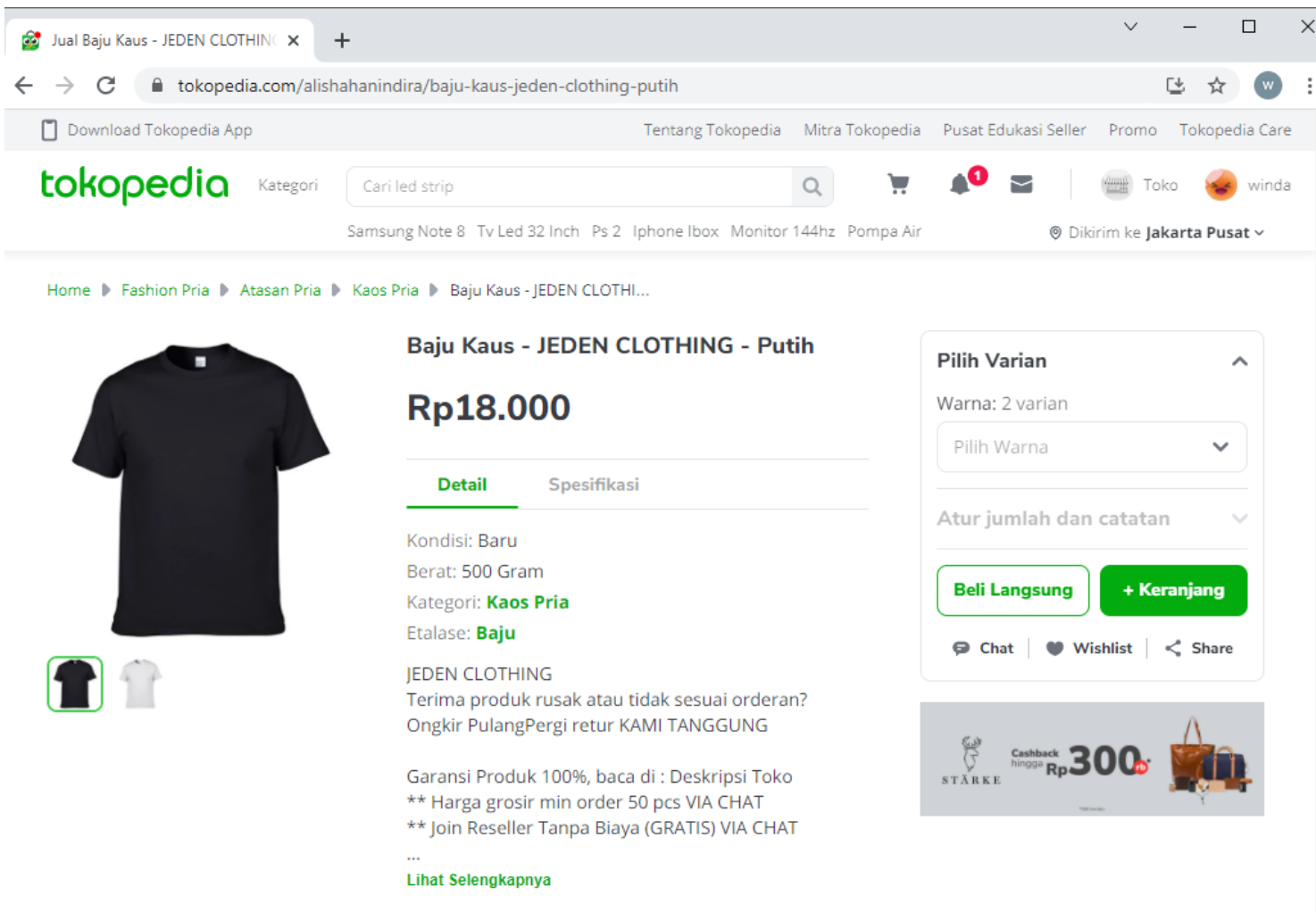

Gambar 6. Tampilan Toko di Halaman Utama Tokopedia

Figure 6 is the main view of the store that has been created and can be seen by consumers and consumers can already buy the product. If a consumer buys a product, the notification goes to the system as well as the registered email and cellphone number for processing. So as a dropshipper, the next step is to contact the owner of the goods to be packaged and sent to consumers through the shipping service chosen by the consumer. When the goods have arrived at the delivery service, the receipt can be uploaded to the system and tracked by the consumer. When the goods have reached the consumer and the courier service delivery closes the delivery system, the balance will be entered into the dropshipper's account.

\section{Conclusion}

The conclusion that can be drawn based on the results of this study is that the Basic Concept of Applying Drop-shipping Methods in E-Commerce to generate new business opportunities for the wider community, especially students, is very wide open and does not require expensive costs. It only takes an understanding of the development of IT and the Internet and the spirit of entrepreneurship to get started. With the Dropshipping Method, anyone can sell goods/services without having a stock of goods/services, but it is enough to cooperate with manufacturers, shops and suppliers.

From the research results on 32 students who participated, the success rate of implementing the dropshipping method in this study was $71.87 \%$, namely 23 students succeeded in selling products while nine other students failed to sell products. It is certainly a reference for development and broad application in creating new business opportunities for students. After students take entrepreneurship courses, the direct practice of becoming a dropshipper can measure the level of students' ability to apply the knowledge they have gained in lectures.

\section{References}

[1] Sherlin. I, "The effect of product innovation and marketing performance on competitive advantage," Benefita Journal, vol. 1 no.3, pp. 105-112, 2016. 
[2] Sulianta Feri, Breakthrough in Selling Online a la Dropshipping++. Andi Yogyakarta, 2014, pp. 2-10

[3] Nanehkaran. Y. A, “An Introduction to Electronic Commerce," International Journal of Scientific \& Technology Research, vol 2(4), pp. 2-5, 2013

[4] Sin. L. G, Purnamasari. R, “China E-Commerc Market Analysis: Forecasting,” Journal of Arts, Science, \& Commerce, vol II , issue 3, pp. 1-9, 2011

[5] Purwati. Y, “Standard Features of E-Commerce User Interface for the Web," Researchers World, vol 2(3), pp. 77-87, 2011

[6] Suroto. B, "Identification of Student Entrepreneurial Spirit (Case Study of Implementation of Excellent Entrepreneurship Program)," Benefita Journal, vol 1, no 3, 154-162, 2016

[7] Boateng. R, Hinson. R, Molla.A, “A Resource-Based Analysis of E-Commerce in Developing Countries," In Proc 18th European Conference on Information Systems, 2010

[8] Durica. M, Svabova. L, "Improvement of Company Marketing Strategy Based on Google Search Results Analysis," Procedia Economics and Finance, vol 26, pp 454-460, 2015

[9] Elvis. F. P, Parulian. S, Research Methods, Sadia Medan, 2012, pp. 17-18

[10] Bambang Mudjiyanto, "Types of Explorative Communication Research," Journal of Communication and Media Studies, vol 22, no 1, pp 65-74, 2018 